1937, appeared the first volume of his results, under the title of an "Atlas of Skeletal Maturation" (St. Louis, 1937). This first volume contains 75 plates giving X-ray photographs of the human hand, each plate representing a certain stage of normal growth. Subsequent volumes were to deal with the growth of other parts and regions of the human body.

Todd made the alimentary tracts of his students the subject of a systematic X-ray survey, his object being to determine what might be the normal dispatch of a bismuth meal in healthy young men, and the extent to which the normal may be departed from within the range of health. His observations were summed up in his Beaumont Lectures of 1930 and published in book form under the title "Behaviour Pattern of the Alimentary Tract".

Todd's object was to lay sure and wide foundations on which other workers might build. He lived and worked to the utmost limit of his bodily and mental strength. He sowed on an immense-an almost unprecedented-scale; it was when he harvested and especially when he came to thresh out and market his grain that his life's endeavour fell short of greatness. ARThur KeIth.

\section{Mr. S. H. Ray}

Mr. Sidney Herbert Ray, whose death was recently announced, was born in London on May 28, 1858. In January 1882 he was appointed by the London School Board as assistant master in the Olga Street School, Bethnal Green, a position which he held until his retirement in May 1923. He was twice married, but had no children. He died on January 1, 1939. By unremitting labour, combined with a peculiar gift for languages, he raised himself to an honoured position in linguistic science. A noticeable characteristic of Ray was the absence of self-seeking ; he worked under conditions which a less devoted man might well have found impossible. Nothing daunted his enthusiasm, and he became a recognized expert in a neglected field of linguistics.

This is not the place to detail his numerous papers on Papuan, Melanesian and Polynesian languages. On suitable occasions he exposed those who juggled with words in order to support vain theories of origins, for the construction of a language and its phonology were to him of prime importance. His studies of particular languages, however, afforded a basis for those wider surveys in which he gave to students the benefit of his erudition.

In 1892, Ray read a paper on the languages of British New Guinea at the Ninth International Congress of Orientalists, in which he showed definitely that there are languages in Now Guinea that differ in vocabulary and grammar from the Melanesian and Polynesian spoken in western Oceania and also from the undoubtedly Melanesian of south-east New Guinea. These non-Melanesian languages he named Papuan as a convenient term for numerous distinct languages with archaic features; about the same time, W. Schmidt made the same deduction for German New Guinea. In 1894, Ray recorded traces of
Papuan languages in various islands of Melanesia. In the same year he demonstrated that the Motu and allied languages of south-east New Guinea were not eastern Polynesian, as had been believed, but were Melanesian. He regarded the languages of the Masim area as originally Papuan upon which have keen grafted words and idioms from Melanesian tongues. Their Papuan origin accounts for their diversity, and the Melanesian element, which is common throughout the area, accounts for their partial agreements.

When Ray visited Torres Straits and British New Guinea (Papua) as a member of the Cambridge Anthropological Expedition to Torres Straits in 1898, he for the first time was able to study various languages from the mouths of the natives, and he was untiring in his endeavour to make the most of his opportunities. His assiduity was such that he continually reduced his informants to exhaustion, while he himself remained quite fresh. In 1907 he published, as volume 3 of the Reports, a monumental work on the languages of New Guinea, which extended and confirmed his previous deductions. He proved that the western language of Torres Straits belonged to the same group as those of northern Australia, and that the eastern language was Papuan and allied to certain languages of the extreme west of Papua.

In 1926, Ray published a comparative study of the Melanesian languages, a further proof of his industry and erudition. In Melanesia there is a linguistic sub-stratum which differs from island to island. Upon this was grafted an immigrant Melanesian language which had spread at an early date from Indonesia and through its simpler grammar and facility of expression obscured the radical differences of the older languages. Later there were colonists from Indonesia who settled mainly on some of the smaller islands and introduced a pidgin-tongue. The words can only rarely be referred to any one original Indonesian language and they form only a small proportion of the vocabulary of any single language. The linguistic diversity in parts of Melanesia suggests that the Melanesian languages were originally variant stocks and that their apparent uniformity has been brought about by the influx of Indonesian words and idioms. This was the first of a projected series of studies, but the expense of their publication prevented the appearance of further volumes. In more favourable circumstances, Ray could have enriched linguistic science to a much greater extent; we can only marvel that, handicapped as he was, he accomplished so much work that will have a lasting value.

\section{A. C. Haddon.}

\section{Prof. E. H. Hall}

Prof. Edwin Herbert Hall, emeritus professor of physics in Harvard University, whose death occurred on November 20, devoted most of his life to the study and investigation of electric conduction. $\mathrm{He}$ will doubtless be most remembered by the Hall effect which he discovered in 1878. This effect is the production of an electromotive force when an electric 
current flows across the lines of force of a magnetic field. This electromotive force is perpendicular both to the magnetic field and to the electric current or, speaking more generally, it is proportional to the vector product of the last two quantities. Other aspects of electrical conduction to which Hall made contributions include the Thomson effect in soft iron, thermo-electric heterogeneity in different metals, the theory of thermo-electric action and of thermal conduction in metals and the relations of the four transverse effects of the magnetic field (the Hall effect was the first of these to be discovered). His keen interest in this field was maintained to the end of his life. In fact, a book entitled "A Dual Theory of Conduction in Metals", in which he summarizes his considered views on the subject, has recently appeared.

Hall was born at Gorham, Maine, on November 7, 1855, and educated at Bowdoin College and Johns Hopkins University. Practically the whole of his working life was spent in the service of Harvard University, in which he joined the Physics Department as an instructor in 1881, became professor in 1895 and emeritus professor in 1921. He attended the Solvay Conference at Brussels on the Conductivity of Metals and Related Problems in 1924 and the Volta Memorial Congress at Como in 1927. He was a member of the National Academy of Sciences, American Association (vice-president in 1904),
American Physical Society (member of Council 1903-6), American Academy of Sciences, and corresponding member of the British Association.

Hall's contributions to physics were not confined to the various aspects of electrical conduction. Among the other subjects he wrote of we find the changes in temperature of the walls of steam engine cylinders, the thermal conductivity of nickel and iron, the deflection of falling bodies and the air resistance to falling inch-spheres. Some of this suggests an interest in engineering as well as in pure physics. He was also the author of several text-books of physics of varying scope.

Hall was a kindly man and a pleasant companion. He was interested in a great variety of matters about which he could speak in an attractive and sometimes humorous way. He kept his interests alive until the end, and his loss will be felt by a wide circle.

O. W. R.

WE regret to announce the following deaths :

Dr. Calvin B. Bridges, known for his work on genetics at Columbia University and the California Institute of Technology, on December 27, aged fortynine years.

Prof. H. H. Woollard, F.R.S., professor of anatomy in University College, London, on January 18, aged forty-nine years.

\section{News and Views}

\section{Scientific and Other Services in War Time}

From time to time in the columns of Nature, reference has been made to the need for full consideration of the part that men of science can take should Great Britain be unhappily involved in a major war. The Association of Scientific Workers has recently had the subject under consideration (see NATURE, Jan. 21, p. 110) and has put forward proposals the fundamental principles of which will, we believe, meet with general approval. A sign that the Government was giving attention to this aspect of national defence was anxiously awaited. The appointment of an advisory council by the Minister of Labour to advise him on the utilization in war time in Government departments or elsewhere of persons with scientific, technical, professional and higher administrative qualifications would appear to be the answer. The representation accorded on the council to scientific interests will not satisfy everyone, but it must be admitted that it is substantial. Sir Walter Moberly has been appointed chairman of the council, and the following have accepted appointment as members : Sir Charles Bressey, Dr. E. J. Butler, Sir Eustace H. Tennyson d'Eyncourt, Mr. S. B. Donkin, Dr. H. L. Eason, Mr. A. H. R. Fedden, Dr. A. P. M. Fleming, Dr. G. S. Gordon, Dr. H. J. Gough, Sir Hector Hetherington, Prof. A. V. Hill, Viscount
Leverhulme, Miss Hilda Martindale, Sir Edward Mellanby, Mr. J. S. Nicholson, Mr. Charles J. G. Palmour, Mr. H. Parker, Sir Robert Pickard, Dr. D. R. Pye, Mr. David E. Roberts, Mr. Basil Sanderson, Mr. T. E. Scott, Sir Frank Smith, Rear-Admiral H. G. Thursfield, Mr. R. S. Wood. The secretary to the Council is Miss B. M. Power, of the National Service Department of the Ministry of Labour, Montagu House, Whitehall, S.W.1.

\section{Dr. Lev T. Berg}

ICHTHYoLogists throughout the world will be interested to learn that Dr. Lev Semenovich Berg, of Leningrad, has recently completed forty years work upon the fishes of his native country. One of his earliest papers, entitled "Ueber Theilung und Bildung des Parablastes bei Esox lucius", was published early in 1899, and from that time onwards a veritable stream of valuable contributions, mainly of a taxonomic nature, has flowed from his pen, and more than one hundred papers bearing his name have appeared in scientific journals throughout the world. Always a patient and careful worker, Dr. Berg has come to be regarded as the foremost authority upon the freshwater fishes of the U.S.S.R., and is a re. cognized authority upon problems concerning the geographical distribution of fishes. His imposing 